\title{
Pharmaceutical excipients - where do we begin?
}

\author{
Alison Haywood, Senior lecturer, School of Pharmacy, Griffith University, Gold Coast \\ Campus; and Beverley D Glass, Professor of Pharmacy, James Cook University, \\ Townsville, Queensland
}

\begin{abstract}
Summary
Excipients have been defined in many ways, including as inert substances used as vehicles and diluents for drugs. The problem with this definition is that in recent years excipients have proved to be anything but inert, not only possessing the ability to react with other ingredients in the formulation, but also to cause adverse and hypersensitivity reactions in patients. These range from a mild rash to a potentially life-threatening reaction. Different brands of the same drug may contain different excipients, especially preservatives and colourants. The Consumer Medicines Information provides a list of excipients, and information on the safety of individual excipients can be found in drug reference guides.
\end{abstract}

Key words: adverse reactions, drug labelling, inactive ingredients, hypersensitivity.

(Aust Prescr 2011;34:112-4)

\section{Introduction}

The word excipient is derived from the Latin excipere, meaning 'to except', which is simply explained as 'other than'. Pharmaceutical excipients are basically everything other than the active pharmaceutical ingredient. Ideally, excipients should be inert, however, recent reports of adverse reactions have suggested otherwise.

\section{What are excipients doing in medicines?}

The best new therapeutic entity in the world is of little value without an appropriate delivery system. ${ }^{1}$ Today, medicines are available in many dosage forms including tablets, capsules, oral liquids, topical creams and gels, transdermal patches, injectable products, implants, eye products, nasal products, inhalers and suppositories. Pharmaceutical excipients are substances that are included in a pharmaceutical dosage form not for their direct therapeutic action, but to aid the manufacturing process, to protect, support or enhance stability, or for bioavailability or patient acceptability. They may also assist in product identification and enhance the overall safety or function of the product during storage or use. ${ }^{2}$
Thousands of different excipients are used in medicines and make up, on average, about $90 \%$ of each product. They represent a market value of $€ 3$ billion (almost $\$ 4$ billion) accounting for $0.5 \%$ of the total pharmaceutical market according to industry experts. ${ }^{3}$

\section{Common excipients used in tablets}

The list of purposes for which excipients are used, as defined in international pharmacopoeias, is extremely long. Many excipients have more than one use, which can be an advantage since it reduces the number of excipients needed and minimises the risk of interactions between them.

Tablets are the most widely used dosage form. Their manufacture can be a complex process and considerable ingenuity and formulation expertise are required to produce a product that will be stable during storage, transport and handling, yet will release its active pharmaceutical ingredient as required once ingested. ${ }^{4}$ Various excipients are used to achieve this (Table 1). ${ }^{2}$

\section{Adverse reactions to excipients}

Ideally, an excipient is pharmacologically inactive, non-toxic, and does not interact with the active ingredients or other excipients. However, in practice few excipients meet these criteria. Toxicity may relate to compounds used as excipients in the final dosage form, or to residues of compounds (such as solvents) used during the manufacturing process. ${ }^{2}$ Table 2 shows examples of adverse reactions that have occurred with excipients.

\section{Colouring agents}

Owing to their widespread and relatively large use in food, a number of colours in current use have been associated with adverse effects, although in a relatively small number of people. ${ }^{5}$ The role of food additives in hyperactive behaviour has been debated for many years. In 2007 a study was published linking the use of six colours (tartrazine, quinoline yellow, sunset yellow, carmoisine, ponceau $4 \mathrm{R}$ and allura red) with behavioural problems in children. However, after reviewing the results of the study, the European Food Standards Agency concluded that no change in legislation was needed. ${ }^{5}$

\section{Identifying reactions to excipients in practice}

When presented with a patient who has an adverse reaction, it is important to be aware that reactions may not always be due 


\section{Table 1}

\section{Common excipients used in tablets}

\begin{tabular}{|c|c|c|}
\hline Excipient & Function & Examples \\
\hline \multirow[t]{2}{*}{ Diluents } & $\begin{array}{l}\text { Provide bulk and enable accurate dosing of potent } \\
\text { ingredients }\end{array}$ & $\begin{array}{l}\text { Sugar compounds e.g. lactose, dextrin, } \\
\text { glucose, sucrose, sorbitol }\end{array}$ \\
\hline & & $\begin{array}{l}\text { Inorganic compounds e.g. silicates, calcium } \\
\text { and magnesium salts, sodium or potassium } \\
\text { chloride }\end{array}$ \\
\hline $\begin{array}{l}\text { Binders, } \\
\text { compression aids, } \\
\text { granulating agents }\end{array}$ & $\begin{array}{l}\text { Bind the tablet ingredients together giving form and } \\
\text { mechanical strength }\end{array}$ & $\begin{array}{l}\text { Mainly natural or synthetic polymers e.g. } \\
\text { starches, sugars, sugar alcohols and cellulose } \\
\text { derivatives }\end{array}$ \\
\hline Disintegrants & $\begin{array}{l}\text { Aid dispersion of the tablet in the gastrointestinal } \\
\text { tract, releasing the active ingredient and increasing the } \\
\text { surface area for dissolution }\end{array}$ & $\begin{array}{l}\text { Compounds which swell or dissolve in water } \\
\text { e.g. starch, cellulose derivatives and alginates, } \\
\text { crospovidone }\end{array}$ \\
\hline Glidants & $\begin{array}{l}\text { Improve the flow of powders during tablet } \\
\text { manufacturing by reducing friction and adhesion } \\
\text { between particles. Also used as anti-caking agents. }\end{array}$ & $\begin{array}{l}\text { Colloidal anhydrous silicon and other silica } \\
\text { compounds }\end{array}$ \\
\hline Lubricants & $\begin{array}{l}\text { Similar action to glidants, however, they may slow } \\
\text { disintegration and dissolution. The properties } \\
\text { of glidants and lubricants differ, although some } \\
\text { compounds, such as starch and talc, have both actions. }\end{array}$ & $\begin{array}{l}\text { Stearic acid and its salts (e.g. magnesium } \\
\text { stearate) }\end{array}$ \\
\hline $\begin{array}{l}\text { Tablet coatings } \\
\text { and films }\end{array}$ & $\begin{array}{l}\text { Protect tablet from the environment (air, light and } \\
\text { moisture), increase the mechanical strength, mask } \\
\text { taste and smell, aid swallowing, assist in product } \\
\text { identification. Can be used to modify release of the } \\
\text { active ingredient. May contain flavours and colourings. }\end{array}$ & $\begin{array}{l}\text { Sugar (sucrose) has now been replaced by film } \\
\text { coating using natural or synthetic polymers. } \\
\text { Polymers that are insoluble in acid, e.g. cellulose } \\
\text { acetate phthalate, are used for enteric coatings } \\
\text { to delay release of the active ingredient. }\end{array}$ \\
\hline Colouring agents & $\begin{array}{l}\text { Improve acceptability to patients, aid identification } \\
\text { and prevent counterfeiting. Increase stability of light- } \\
\text { sensitive drugs. }\end{array}$ & $\begin{array}{l}\text { Mainly synthetic dyes and natural colours. } \\
\text { Compounds that are themselves natural } \\
\text { pigments of food may also be used. }\end{array}$ \\
\hline
\end{tabular}

Table 2

Common examples of adverse reactions to excipients 2,5

\begin{tabular}{|c|c|c|}
\hline Excipient & Function & Caution in practice \\
\hline Tartrazine & Colouring agent & Reported cases of hypersensitivity, and hyperkinetic activity in children \\
\hline Aspartame & Sweetener & Caution in patients with phenylketonuria \\
\hline $\begin{array}{l}\text { Benzalkonium } \\
\text { chloride }\end{array}$ & Preservative & $\begin{array}{l}\text { Bronchoconstriction (nebuliser solutions) and ocular toxicity (soft contact } \\
\text { lens solutions) }\end{array}$ \\
\hline $\begin{array}{l}\text { Sodium } \\
\text { metabisulphite }\end{array}$ & Antioxidant & $\begin{array}{l}\text { Hypersensitivity, including bronchospasm and anaphylaxis, are reported } \\
\text { for all sulphites }\end{array}$ \\
\hline Propyl gallate & Antioxidant & Contact sensitivity and skin reactions \\
\hline Lactose & Tablet filler & $\begin{array}{l}\text { Caution in patients with galactosaemia, glucose-galactose malabsorption } \\
\text { syndrome, or lactase deficiency }\end{array}$ \\
\hline Sesame oil & Oil (injections) & Hypersensitivity reactions reported \\
\hline Lanolin (wool fat) & Emulsifier (topical products) & Skin hypersensitivity reactions, caution in patients with known sensitivity \\
\hline
\end{tabular}


to the active ingredient (Fig. 1). They are more likely to occur if the patient has an existing sensitivity to similar ingredients, or is on multiple medicines, or when the quantity of excipients may be high relative to body weight, for example in premature babies. ${ }^{6}$ Excipients present in their current and past medication history should also be considered. This will help to rule out which ingredients may be causing the adverse effects.

\section{Finding information on excipients}

The Consumer Medicine Information leaflet, which is often readily available online (www.nps.org.au/search_by_medicine_name), will have a list of the excipients included in the medicine. This list can be found under 'Product description' and may be titled 'Other ingredients' or 'This product also contains...'

The Pharmacopoeias (US Pharmacopoeia, British

Pharmacopoeia) contain monographs for many excipients.

However, not all excipients reach these texts due to companies withholding data because of concerns about releasing proprietary information. The Handbook of Pharmaceutical Excipients contains monographs for 340 excipients, with each monograph including a 'Safety' section that presents adverse reactions that have been reported. ${ }^{5}$ Martindale ${ }^{2}$ has safety information on excipients and is a required text for hospital and community pharmacists. The monographs for each excipient contain a section on adverse effects reviewed from the literature.

\section{Conclusion}

Medicines contain ingredients other than the active drug that are essential for their manufacture, stability and function. These ingredients should be inert, however they do have the potential to cause adverse effects in sensitive individuals. Identifying such reactions and finding the appropriate safety information will help to ensure a safe outcome for the patient.

\section{References}

1. Augsburger LL, Zellhofer MJ. Tablet formulation. In: Swarbrick J, Boylan JC, editors. Encyclopedia of pharmaceutical technology. 3rd ed. New York: Marcel Dekker; 2006.

2. Martindale: The complete drug reference. 37th ed. London: Pharmaceutical Press; 2011. (electronic and hard copy available)

3. International Excipients Certification Project: minimize risks maximize benefits. London: Pharmaceutical Quality Group; 2009.

4. Armstrong NA. Tablet manufacture. In: Swarbrick J, Boylan JC, editors. Encyclopedia of pharmaceutical technology. 3rd ed. New York: Marcel Dekker; 2006.

5. Rowe RC, Sheskey PJ, Quinn ME, editors. Handbook of pharmaceutical excipients. 6th ed. London: Pharmaceutical Press; 2009.

6. What are excipients doing in medicinal products? Drug Ther Bull 2009;47:81-4.

Conflict of interest: none declared

Fig. 1

Pharmaceutical excipients - managing the risk in practice

\begin{tabular}{|c|c|}
\hline $\begin{array}{l}\text { Patient presents } \\
\text { with allergy }\end{array}$ & $\begin{array}{c}\text { Patient has a } \\
\text { history of allergies }\end{array}$ \\
\hline
\end{tabular}

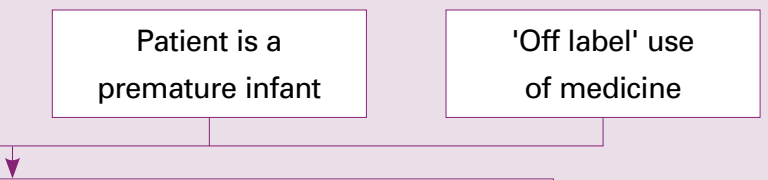

Step 1 Check ingredient list in Consumer Medicines Information

- Does patient have known allergies to any ingredients listed in the Consumer Medicines Information?

- Are similar excipients present in any of their past medicines?

- Is the patient on multiple medicines containing the same excipients?

\section{$\checkmark$}

Step 2 Check resources such as Martindale

- Does the monograph for that ingredient have any safety warnings?

- Are any adverse reactions listed for that ingredient?

$\checkmark$

\section{Step 3 Consider other options}

- Does switching to a different brand of tablets alleviate symptoms?

- Does switching to a different dosage form (e.g. patch) alleviate symptoms? 